López-Álvarez, R. L., Luna-Cavazos, M., Valdez-Hernández, J. I., \& García-Moya, E. (2021). Tree structure and diversity of a Humid Mountain Forest in the protected natural area La Martinica, Veracruz, Mexico. Revista de Biología Tropical, 69(4), 1189-1203. https://doi.org/10.15517/rbt. v69i4.46855

\title{
Tree structure and diversity of a Humid Mountain Forest in the protected natural area La Martinica, Veracruz, Mexico
}

\author{
Rosa Lina López-Álvarez¹; (D) https://orcid.org/ 0000-0002-2543-0694 \\ Mario Luna-Cavazos ${ }^{1 *}$; (D) https://orcid.org/0000-0003-1672-8154 \\ Juan Ignacio Valdez-Hernández ${ }^{2}$; (D) https://orcid.org/0000-0002-9488-2790 \\ Edmundo García-Moya ${ }^{1}$; (D) https://orcid.org/0000-0003-1100-8553
}

1. Posgrado en Botánica, Colegio de Postgraduados, Campus Montecillo, México; lopz.lina@gmail.com, mluna@colpos.mx (*Correspondence), edmundo@colpos.mx

2. Posgrado en Ciencias Forestales, Colegio de Postgraduados, Campus Montecillo, México; ignaciov@colpos.mx

Received 04-V-2021. Corrected 08-X-2021. Accepted 04-XI-2021.

\begin{abstract}
Introduction: The Humid Mountain Forest (HMF) has the highest number of plants per unit of surface, whose vegetation grows under heterogeneous environmental conditions and possess a high floristic variation. HMF conservation is important due to the biodiversity it harbors and the environmental services it provides.

Objective: This work evaluated the effect of the terrain aspect and density of the forest canopy on the structure and tree diversity in La Martinica Protected Natural Area, Mexico.

Methods: Stratified sampling was performed in four terrain aspects and two canopy density conditions. Twenty five sampling units of $20 \times 25 \mathrm{~m}$ were considered, in which the normal diameter (ND), total height and the largest and smallest diameters of the crown of the individuals with a ND $\geq 10 \mathrm{~cm}$ were registered. The diversity was estimated by rarefaction curves and the structure was analyzed through the importance value index (IVI) and the forest value index (FVI).

Results: 37 species belonging to 30 genera and 24 families were recorded. Greater diversity was observed in the north terrain aspect and in the closed canopy. Tree species with the highest structural values were different between terrain aspect and canopy types; Carpinus tropicalis presented the highest values in the zenithal terrain aspect, Lippia myriocephala in the east and south terrain aspect, and Liquidambar styraciflua in the north. In both canopy types Lippia myriocephala obtained the highest IVI values and FVI in the open canopy; Carpinus tropicalis reached a higher FVI in the closed canopy.

Conclusions: Tree structure was different in the four terrain aspects and two canopy conditions studied. The greatest difference in species composition and diversity was observed between the north and east terrain aspects; the north presented the highest richness values, frequent and dominant species.
\end{abstract}

Key words: canopy opening; effective number of species; NMDS; terrain aspect; tree vegetation.

The Humid Mountain Forest (HMF) is one of the most important biomes in Mexico, has a great richness of flora and endemic species, due to the great variety of habitats and the restricted to a small geographical area (Cruz-Cárdenas et al., 2012; González-Espinosa et al., 2011); its vegetation harbors the largest number of species per unit area (Gual-Díaz \& RendónCorrea, 2014; Gual-Díaz \& Rendón-Correa, 2017; Villaseñor, 2010). At the national level, 
the humid mountain forest is one of the most threatened ecosystems (González-Espinosa et al., 2012; Toledo-Aceves et al., 2011), due to its scarce distribution and the alterations caused by global climate change, deforestation, the expansion of human communities to mountainous areas where this forest persists, and changes in land use due to conversion to crop systems (Cayuela et al. 2006; GonzálezEspinosa, et al., 2011; Gual-Díaz \& RendónCorrea, 2017).

The Humid Mountain Forest has also been described as cloud forest and mountain cloud forest (Rzedowski, 2006). It develops between 800 and $3000 \mathrm{~m}$ above sea level, in the mountainous regions of Mexico, on the slopes where the humid winds that come from the sea affect, and generally between 1000 and $3000 \mathrm{~m}$ of altitude (Villaseñor, 2010) to the windward of mountain massifs, where moisture condenses and fogs form, as well as in ravines and humid slopes (Challenger \& Soberón, 2008; Rzedowski, 2006; Villaseñor, 2010). The HMF is characterized by having a very dense tree canopy, which limits the passage of light to the lower strata (Challenger \& Soberón, 2008; CONAFOR \& COLPOS, 2014). Its vegetation develops in very heterogeneous climatic, altitudinal and edaphic conditions and the orographic and local humidity conditions that characterize it, originate a wide structural variability in the form of various associations that differ from each other in height, phenology and dominant species (Gual-Díaz \& RendónCorrea, 2014; Rzedowski, 2006). In addition, HMF contains floristic elements of different biogeographic affinity whose presence creates a great opportunity to evaluate the relationships among factors as climate, microenvironment, changes in vegetation structure, and its floristic composition (González-Espinosa et al., 2011; Guerrero-Hernández et al., 2019).

Slopes facing north, in the northern hemisphere, tend to be more humid, which benefits different plant species; unlike south-facing slopes which receive more solar radiation and tend to be drier and warmer (Holland \& Steyn 1975; Mata-González et al., 2002; Renaud et al., 2011), thus the aspect is a factor that can modify, at a local level, essential variables of plant functions, such as the quantity and quality of incident radiation, temperature or frost frequency (Torres et al., 2012). The foregoing affected, for example, the presences of HMF patches studied by Luna-Vega et al. (2007), one oriented to the north and the other to the southwest, in which these authors found differences in ecological attributes as the number of individuals per ha, basal area $\left(\mathrm{m}^{2} / \mathrm{ha}\right)$, species richness, crown cover and normal diameter. It is important to mention that these ecological attributes have a differential impact on the structure and diversity of the HMF in different environments. Williams-Linera et al. (2013) in a study of the HMF (which they call Cloud Forest) of central Veracruz, they mention that these types of forests located at low altitudes are less diverse, and more similar in composition, unlike forests located at higher elevations, but not found differences in the structure of vegetation in forests located at different altitudes.

Santana et al. (2014), analyzed the biodiversity and structure in fragments of the HMF (described as Bosque Mesófilo de Montaña) of Michoacán, México; the authors mention that diversity, similarity, and structure demonstrate significant heterogeneity in HMF fragments. García-De la Cruz et al. (2013) mention, that the alpha diversity of one of the studied sites for a mountain cloud forest of Veracruz, México, was significantly higher than the other two sites; similarly, the plant structure between sites was different, which was attributed to the management history and natural disturbances that favor the establishment and development of different species. Luna-Vega et al. (2007) carried out a structural analysis of two fragments of mountain cloud forest of the Trans-Mexican Volcanic Belt; the authors refer that the two sites have densities of 740-1 720 individuals per hectare, differ in basal area, and foliage coverage. García-Franco et al. (2008) analyzed the vegetation of the Mountain Cloud Forest in three sites in the center of Veracruz, Mexico; the authors mentioned that there were no significant differences for basal area between 
sites; in addition, the greatest floristic differences were found between sites further away from each other. Based on the aforementioned, the close relationship that exists between the ecological attributes mentioned above with the structural characteristics and diversity of the HMF can be observed. In the case of the HMF located at west of Xalapa, Veracruz, WilliamsLinera et al. (2002) pointed out that the best conserved forests are on very steep slopes, facing north, while the disturbed forests they are located mainly to the south facing slopes.

The conservation of the HMF is important for the biodiversity it encloses and for its contribution to the maintenance of environmental regulation services (CONAFOR \& COLPOS, 2014; Manson, 2017; Williams-Linera, 2007). Nevertheless, in the central region of Veracruz this biome is fragmented. The edges of the remnants experience changes in physical conditions, such as variations in the microclimate and, they are under pressure from the expansion of urban settlements (Williams-Linera et al., 2002; Williams-Linera, 2007).

Williams-Linera et al. (2002), report that the Humid Mountain Forest of the central Veracruz, Mexico, has been considerably reduced since the 1960s due to the transformation of the forest for pastures and crops, along with urban growth. Deforestation processes continue in this area (Williams-Linera et al., 2007), so the HMF is at risk. The PNA La Martinica is located within the aforementioned area, so it is subject to the same problems already mentioned. Among the various actions to reduce the deterioration of the HMF, it has been proposed to register the conditions and changes in the environment necessary to prevent negative impacts on the forest conservation; also, enrich the knowledge of the identity and distribution of the region's biodiversity (Williams-Linera et al., 2007). The HMF of the central region of Veracruz is highly fragmented, La Martinica is one of the few remnants that are under protection in order to be preserved, its importance lies in its value as a reserve of biological diversity and it is of great significance to maintain environmental services such as the regulation of water resources (Williams-Linera et al., 2007).

We consider that our study contributes to the knowledge of the current state of the tree vegetation in this important area of HMF in the center of Veracruz state, with which we can generate proposals for the conservation of the tree diversity of this region. Based on the above, the aim of this work was to evaluate the influence of terrain aspect and canopy density on the structure and diversity of tree vegetation in the Humid Mountain Forest at the natural protected area La Martinica, Banderilla, Veracruz. We asked the following questions: (i) do terrain aspect influence structure, diversity and tree species composition? (ii) do canopy density influence structure, diversity and tree species composition? As hypotheses, we assumed that: (i) structure, diversity and tree species composition is different between terrain aspects and particularly north aspect has a positive influence on them (ii) closed canopies have a positive influence on structure, diversity and tree species composition.

\section{MATERIALS AND METHODS}

Study Area: The study area is located in the Natural Protected Area (NPA) La Martinica, Banderilla, Veracruz, Mexico (Fig. 1), between $19^{\circ} 35^{\prime} 01.3$ ' $-19^{\circ} 35^{\prime} 27.9^{\prime \prime} \mathrm{N} \&$ $96^{\circ} 56^{\prime} 52.7^{\prime}$ ' $96^{\circ} 57^{\prime} 30.4$ " W. The site was a private property where extensive cattle ranching was developed and was decreed as a stateowned protected area in 2010. It has an area of 52.36 ha, of which near to 30.5 ha are covered by forest vegetation (hillsides), and the rest are remnants of induced grasslands which is partially in restoration process (non-sloping area) (Herrera-Beltrán, 2010; SEDESMA, 2006).

La Martinica has plateaus and slopes with angles from 2 to $45^{\circ}$, the area belongs to the Neovolcanic province and is distributed in an altitudinal range between 1570 and 1620 m.a.s.l., andosol is the predominant soil type, the average temperature is $18{ }^{\circ} \mathrm{C}$ with an oscillation of 5 to $7{ }^{\circ} \mathrm{C}$ and the total annual precipitation fluctuates between 1500 and $2000 \mathrm{~mm}$ 


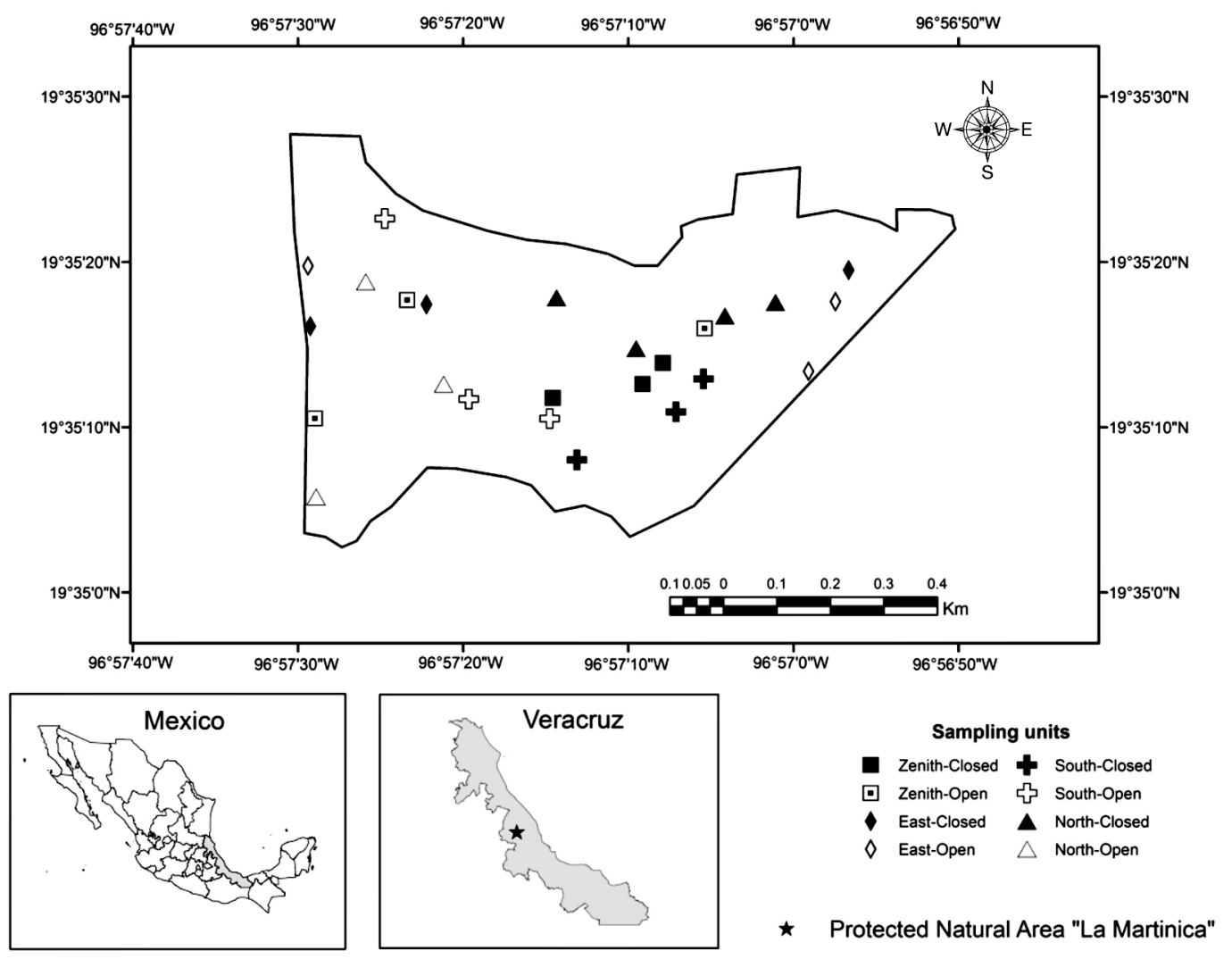

Fig. 1. Location of the study area and distribution of the sampling units in the Protected Natural Area "La Martinica", in the municipality of Banderilla, Veracruz, Mexico.

(SEDESMA, 2006). The climate corresponds to temperate $\mathrm{C}(\mathrm{fm}) \mathrm{b}\left(\mathrm{i}^{\prime}\right)$ with an ample cool summer, abundant rain all year round and little thermal oscillation (García, 2004). The vegetation corresponds to a humid mountain forest and the most typical characteristic species, we can find Liquidambar styraciflua L., Clethra mexicana DC, Carpinus tropicalis (Donn. Sm.) Lundell, Ostrya virginiana (Mill.) Koch, and Quercus spp. L (Villaseñor, 2010).

Sampling and measuring variables: A stratified sampling was carried out in four terrain aspects (sampling unit): zenithal (Z), east $(\mathrm{E})$, north $(\mathrm{N})$ and south $(\mathrm{S})$. The forest was classified based on canopy densities in: closed canopy (C), areas with a smaller opening $(21.8 \pm 0.79)$, and open canopy $(\mathrm{O})$, where the opening percentage was bigger $(26.23 \pm$ 0.82 ), a generalized linear model for a Gaussian distribution was used to determine whether canopy opening varied significantly between sites, the test showed that there is a significant difference $\mathrm{P}<0.0001$. The estimation of the gaps in each sampling subunit was made through photographs taken at $1.6 \mathrm{~m}$ from the ground (250 in total) at approximately 10:00 in the morning, with a Nikon COOLPIX B500 camera. Images were analyzed with CobCal software version 1.0 (Ferrari et al., 2006), to estimate the opening percentage. This method is based on colorimetry, and the coverage percentage is calculated. Positive colors (represent the vegetative surface to be calculated) and negative colors (representative of the surface to be discarded from calculation) were assigned to 
the photograph. The West aspect was not considered because the open canopy condition was poorly represented in that aspect.

The sampling method of Endara-Agramont et al. (2012) was adapted to each terrain aspect and canopy type. Six sampling units (SU) of $20 \times 25$ (500) were arranged in each aspect. Three SUs were located in each canopy type ( 3 in $\mathrm{Z}-\mathrm{C}$ and 3 in $\mathrm{Z}-\mathrm{O}$ ), with the exception of north aspect with closed canopy condition where four SUs were installed, because it was the most extensive area, for a total of 25 SUs, equivalent to 1.25 ha. Each SU was divided into 10 subunits $10 \times 5 \mathrm{~m}\left(50 \mathrm{~m}^{2}\right)$ in which the trees were numerated to facilitate counting. Normal diameter (ND) was recorded at $1.3 \mathrm{~m}$ height from the ground. Total height was estimated, and also upper and lower crown diameters of every individual with a ND $\geq 10$ $\mathrm{cm}$ were measured.

Some species were collected, and photographs taken for later taxonomic identification with specific available literature, i.e. Barcena (1981), Fernández-Nava (1986), LudlowWiechers (1978), Nash \& Nee (1984), Nee (1981), and Pacheco (1983). The Angiosperm Phylogeny Group classification was followed (APG IV, 2016; Stevens, 2017). The nomenclature was verified by consulting the Missouri Botanical Garden database (TROPICOS, 2018). Collected specimens were deposited in the CHAPA herbarium of Colegio de Postgraduados, Mexico.

Structure and diversity: The structure analysis of tree species on each terrain aspect and canopy type was based on the estimation of the importance value index (IVI $=$ relative dominance + relative density + relative frequency) (Curtis \& McIntosh, 1951; SánchezGutiérrez et al., 2017) and the forest value index $(\mathrm{FVI}=$ relative ND + relative height + relative cover) (Corella-Justavino et al., 2001; Ortega-Baranda et al., 2017).

The diversity between terrain aspects and forest canopy types was compared in units of effective number of tree species. The procedure proposed by Chao \& Jost (2012) and
Chao et al. (2014) was used, by interpolation and extrapolation of estimates from diversity rarefaction curves ${ }^{q} D$ (y-axis) as a function of sampling coverage

$$
\hat{C} n=1-\frac{f_{1}}{n}\left[\frac{(n-1) f_{1}}{(n-1) * f_{1}+2 f_{2}}\right]
$$

(x-axis), where species richness $(q=0)$, exponential of Shannon entropy $(q=1)$, and inverse of the Simpson concentration $(q=2)$. Therefore, ${ }^{0} D=$ number of species, ${ }^{1} D=$ effective number of equally frequent species, and ${ }^{2} D=$ effective number of dominant species. $f_{l}$ is the number of species of which only one individual was registered during the sampling, $f_{2}$ is the number of species with two individuals, and $n$ is the total number of registered individuals (Cultid-Medina \& Escobar, 2019). Estimations were done in R software using "iNEXT" package (Hsieh et al., 2020; R Core Team, 2019).

Statistical analyses: The effect of the aspects and types of canopies over plant composition were evaluated by a permutational multivariate analysis of variance (PERMANO$\mathrm{VA})$ for a factorial arrangement $4 \times 2$. Also, the similarity in species composition among aspects and type of canopy was evaluated through non-metric multidimensional scaling (NMDS), which produces a ranking based on a dissimilarity matrix. The analyses were based on 999 permutations using the Bray-Curtis distance as a measure of similarity, with the transformation of the data to square root. These analyses were conducted with R software using "Vegan" package (Oksanen et al., 2019; R Core Team, 2019).

The association among tree species and terrain aspects was based on a correspondence analysis. A frequency matrix of individuals from each species in their respective aspect was elaborated. This analysis was carried out in R software using "CA" package (Nenadic \& Greenacre, 2007; R Core Team, 2019).

The effect of the aspect and type of canopy, on the basal area $\mathrm{m}^{2}$ and tree density (ind. $\mathrm{x} 500$ $\mathrm{m}^{2}$ ), was determined using a generalized linear model (Crawley, 2012) with a 4 × 2 factorial 
arrangement for a Gaussian error distribution in the case of basal area and quasi-Poisson for density. When significant differences were found, they were contrasted in pairs by the Holm adjustment method, analysis were done with the program $\mathrm{R}$ using the 'Phia' package (R Core Team, 2019; Rosario-Martinez, 2015).

\section{RESULTS}

Individuals of 779 trees were recorded which belong to 37 species, distributed in 30 genera and 24 families. The tree species with the highest structural values in La Martinica were the same for both indices (IVI and FVI). The five species being remarkable abundant were: Lippia myriocephala $(\mathrm{IVI}=17.2 \%$, FVI $=16.9 \%$ ), Carpinus tropicalis (IVI $=12 \%$, FVI $=12.3 \%)$, Myrsine coriacea $($ IVI $=11.27$
$\%$, FVI $=10.74 \%$ ), Liquidambar styraciflua $(\mathrm{IVI}=9.14 \%$, FVI $=9.69 \%)$, and Trema micrantha (IVI $=8.24 \%$, $9.63 \%$ FVI) (Appendix 1). The most important species were different among terrain aspects. C. tropicalis had the highest values on $\mathrm{Z}$ aspect (IVI $=17.75 \%$, FVI $=18.2 \%)$, L. myriocephala on E (IVI $=25.36$ $\%, \mathrm{FVI}=25 \%)$ and $\mathrm{S}$ aspects (IVI $=21.11 \%$, $\mathrm{FVI}=19.4 \%$ ), and L. styraciflua on $\mathrm{N}$ aspect $(\mathrm{IVI}=18.37 \%, 20.2 \%=\mathrm{FVI})($ Appendix 2$)$. By contrast, in both types of canopy L. myriocephala had the highest IVI values: at O (22.9 $\%$ ) and at C (11.84\%), and only FVI in the O canopy type $(22.9 \%)$, due to the fact that $C$. tropicalis had a highest FVI in C canopy areas (12.1\%) (Appendix 3).

All the diversity expressions $\left({ }^{0} D,{ }^{1} D\right.$ and ${ }^{2} D$ ) were significantly higher in the $\mathrm{N}$ aspect. In fact, no significant differences were observed

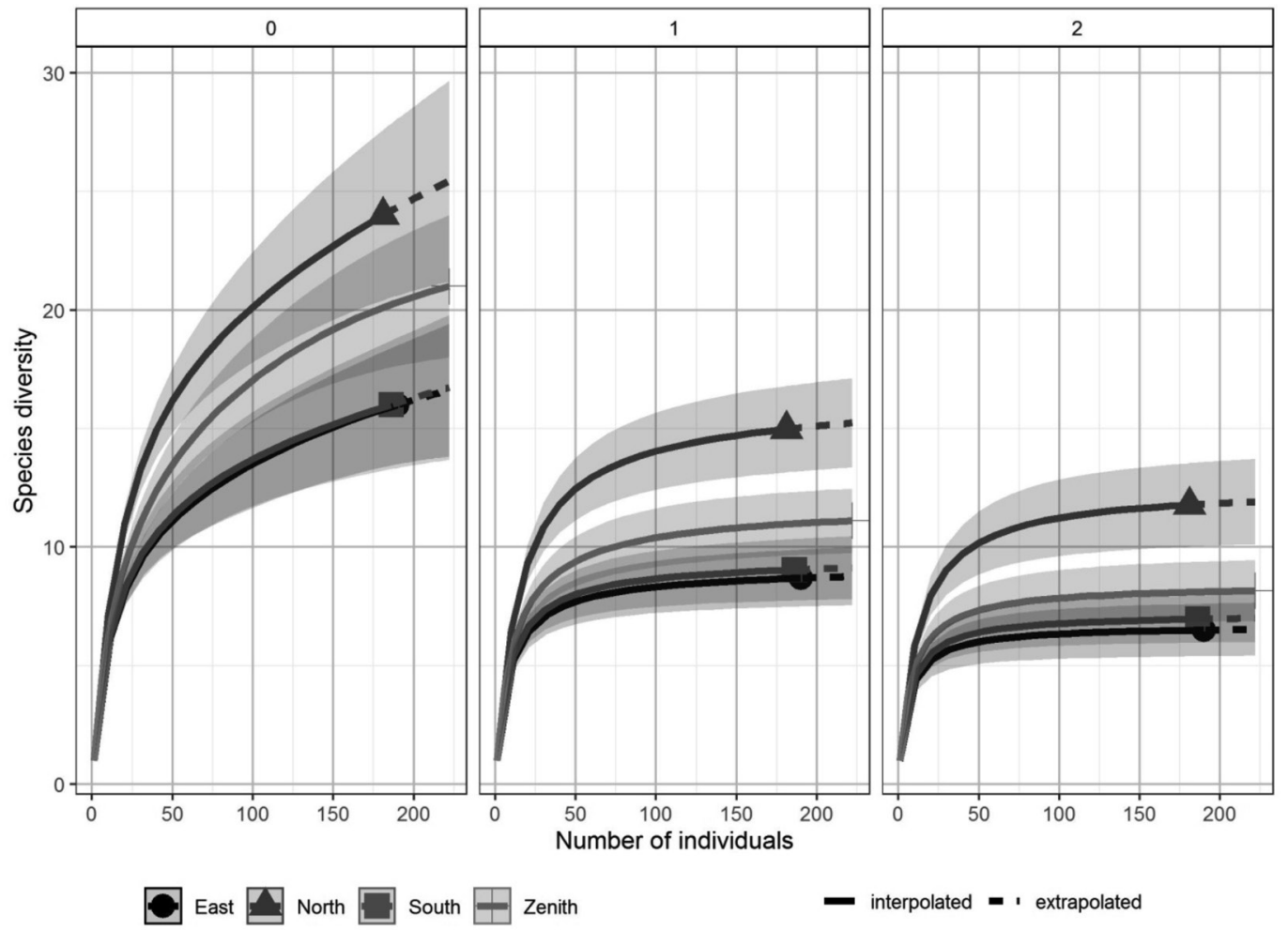

Fig. 2. Rarefaction curves with $95 \%$ CI, constructed based on the coverage of the trees registered according to terrain aspect. In the upper part, the order of diversity is shown: ${ }^{0} D=$ number of species, ${ }^{1} D=$ effective number of equally frequent species, and ${ }^{2} D=$ effective number of dominant species. Curves were extrapolated to the total abundance observed in the zenithal exposure $(\mathrm{N}=222$ individuals $)$. 
in relation to the effective number of common species and abundant species between $\mathrm{Z}, \mathrm{E}$ and $\mathrm{S}$ aspects. Nevertheless, when sampling areas above $50 \%$ coverage, richness in $\mathrm{Z}$ aspect was significantly higher than in $\mathrm{E}$ and $\mathrm{S}$ exposures (Fig. 2). According to canopy types, the same trend was observed for all diversity expressions $\left({ }^{0} D,{ }^{1} D\right.$ and $\left.{ }^{2} D\right)$, since they were significantly higher in $\mathrm{C}$ canopy (Fig. 3).

Tree structure in terms of composition and density showed significant differences between terrain aspects, the post-hoc test indicates that the main difference was found between the $\mathrm{E}$ and $\mathrm{N}$ aspects (Table 1), as it is depicted by the NMDS (Fig. 4) with a good fit represented in two dimensions (stress $=0.17$ ). According to canopy types, no significant differences were found.
Correspondence analysis explained about $87 \%$ of the total variance of the species in two dimensions. Species such as $O$. virginiana, Quercus germana Schltdl. \& Cham., and L. styraciflua tended to be more frequently associated with the $\mathrm{N}$ aspect; $C$. tropicalis and Rhamnus capreifolia Schltdl. with Z aspect; Lippia myriocephala Schltdl. et Cham., Myrsine coriacea (Sw.) R. Br. ex Roem. \& Schult., Quercus xalapensis Bonpl. and Trema micrantha (L.) Blume, with E and S terrain aspects (Fig. 5).

Basal area of the individuals varied significantly between terrain aspects. However, it was not significantly different between canopy types, and a significant interaction of factors was not observed either. Afterwards comparisons show that $\mathrm{N}$ aspect is the one that differs from other aspects, obtaining record of the largest basal area (Table 2).

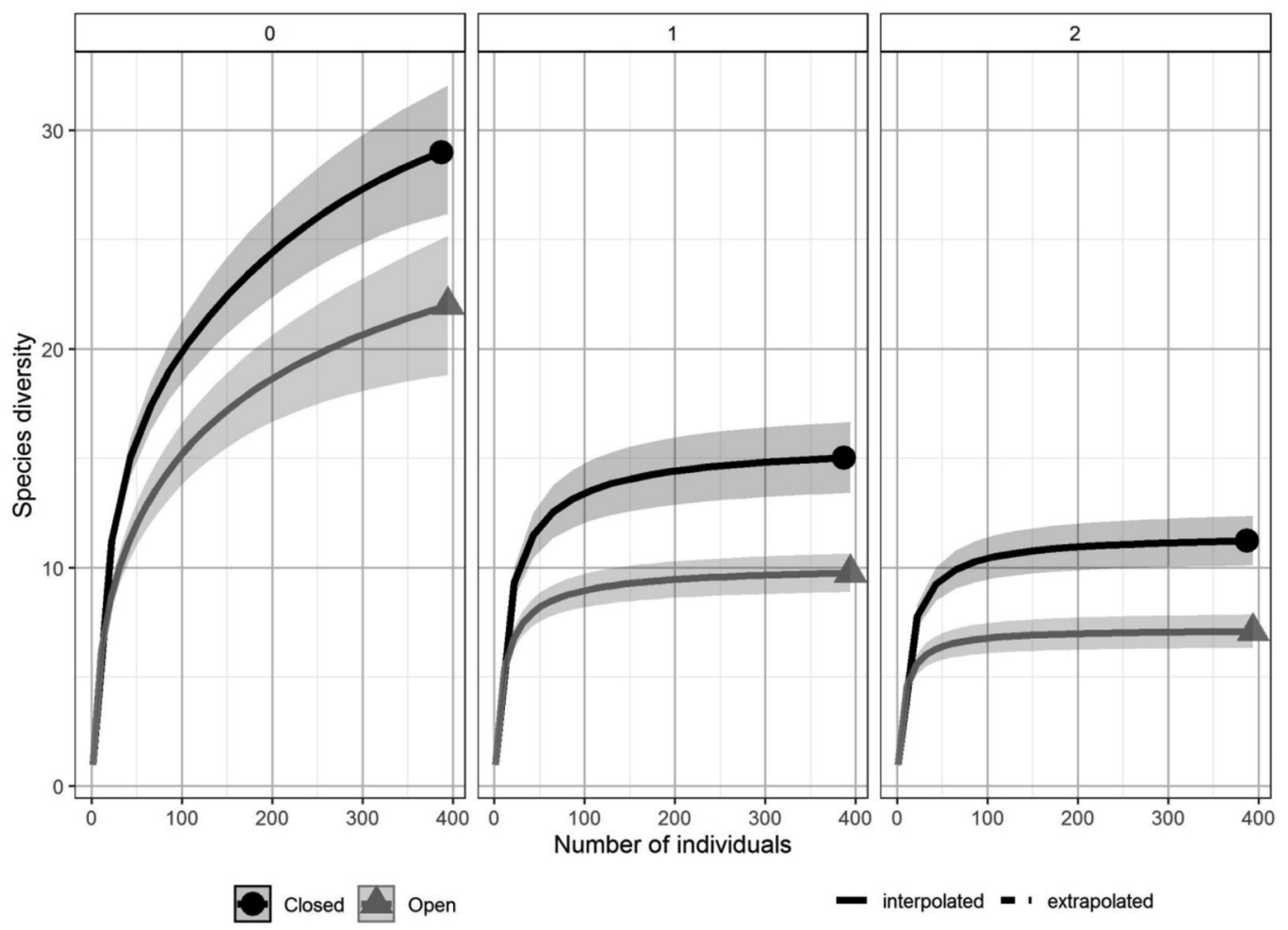

Fig. 3. Rarefaction curves with $95 \%$ CI, constructed based on the coverage of the trees recorded by canopy condition. In the upper part, the order of diversity is shown: ${ }^{0} D=$ number of species, ${ }^{1} D=$ effective number of equally frequent species, and ${ }^{2} D=$ effective number of dominant species. Curves were extrapolated to the total abundance observed in the open canopy ( $\mathrm{N}=394$ individuals). 
TABLE 1

PERMANOVA results for the composition of tree species

\begin{tabular}{|c|c|c|c|c|c|c|}
\hline Source & $\mathrm{df}$ & & Pseudo-F & $\mathrm{P}$ & \multicolumn{2}{|c|}{ Post-hoc comparisons } \\
\hline Canopy & 1 & 0.0821 & 2.1754 & $0.026 * *$ & Exposure & $\mathrm{P}$ \\
\hline Exposure & 3 & 0.1788 & 1.5797 & $0.062 *$ & Z-E & 0.2 \\
\hline Canopy:Exposure & 3 & 0.0975 & 0.8612 & 0.651 & $\mathrm{Z}-\mathrm{N}$ & 0.236 \\
\hline Residual & 17 & 0.6415 & & & $\mathrm{Z}-\mathrm{S}$ & 0.842 \\
\hline \multirow[t]{5}{*}{ Total } & 24 & 1 & & & E-N & 0.017 \\
\hline & & & & & E-S & 0.548 \\
\hline & & & & & $\mathrm{N}-\mathrm{S}$ & 0.355 \\
\hline & & & & & Canopy & $\mathrm{P}$ \\
\hline & & & & & $\mathrm{O}-\mathrm{C}$ & 0.448 \\
\hline
\end{tabular}

** Significance at 0.05 , * significance at 0.1 . the design was factorial $4 \times 2$ considering the condition of the canopy and the exposure of the terrain. $\mathrm{Z}=$ zenithal, $\mathrm{E}=$ east, $\mathrm{N}=$ north, $\mathrm{S}=$ south, $\mathrm{O}=$ open, $\mathrm{C}=$ closed.

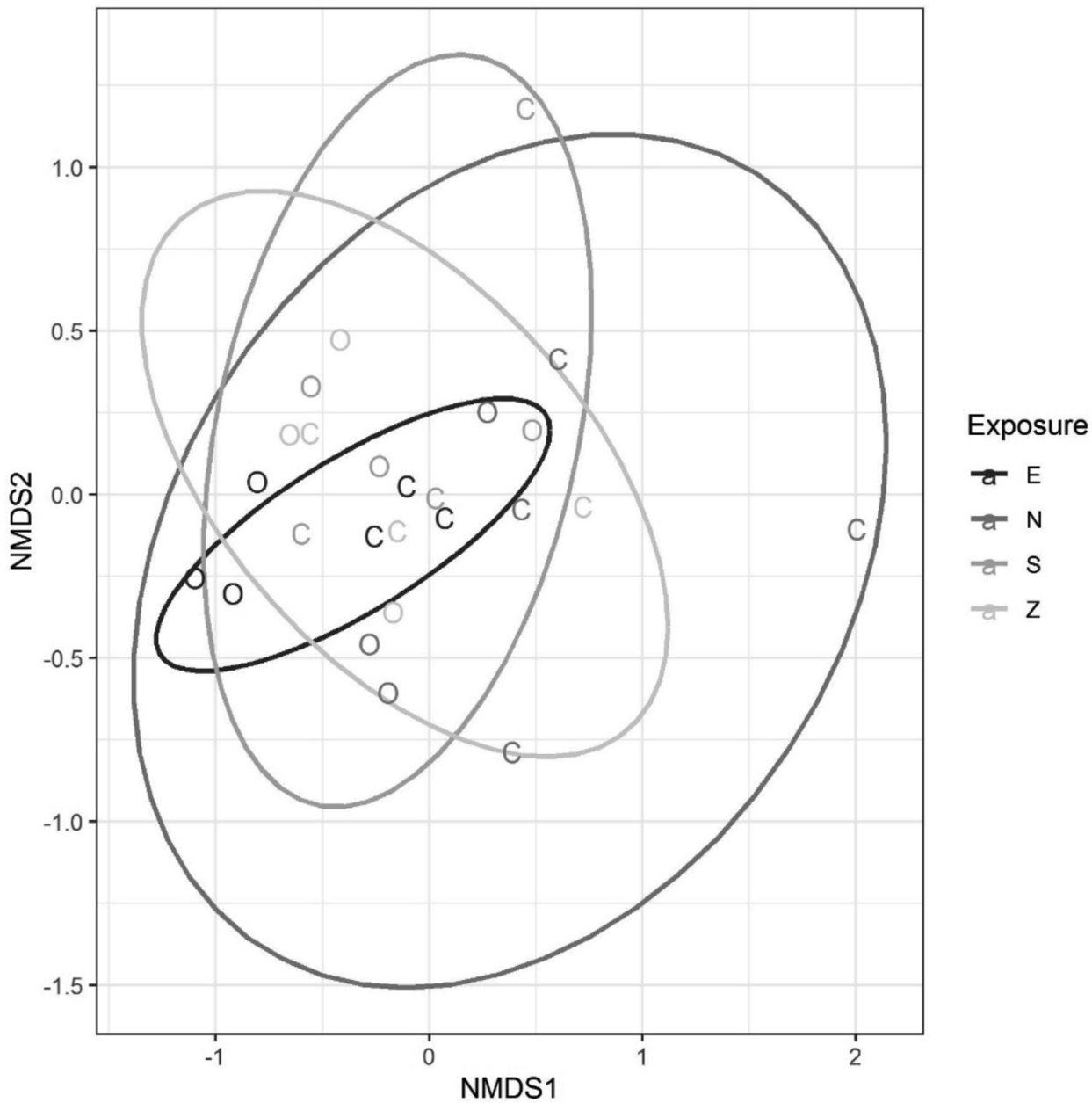

Fig. 4. Non-metric multidimensional scaling of the tree communities recorded in four exposures $(Z=$ zenithal, $E=$ east, $\mathrm{N}=$ north, $\mathrm{S}=$ south $)$, and two canopy conditions $(\mathrm{O}=$ open and $\mathrm{C}=$ closed $)$, in the protected natural area La Martinica, municipality of Banderilla, Veracruz, Mexico (good fit $=0.17$, Bray-Curtis distance index). 
TABLE 2

Statistical results of the generalized linear model on basal area of trees, in a 4 × 2 factorial arrangement considering the canopy opening condition and the direction of sun exposure of the terrain (aspect), and post-hoc comparisons

\begin{tabular}{|c|c|c|c|c|c|c|c|}
\hline \multirow{2}{*}{$\begin{array}{l}\text { Condition } \\
\text { E Exposure }\end{array}$} & \multirow{3}{*}{-0.164} & \multirow{2}{*}{$\begin{array}{c}\mathrm{P} \\
0.8694 \\
\end{array}$} & \multicolumn{4}{|c|}{ Condition } & \multirow{2}{*}{$\begin{array}{c}\mathrm{P} \\
0.0625^{*}\end{array}$} \\
\hline & & & \multirow{7}{*}{$\begin{array}{c}\text { Post-hoc } \\
\text { comparisons }\end{array}$} & \multirow[t]{4}{*}{ Canopy } & $\mathrm{O}-\mathrm{C}$ & 3.469 & \\
\hline & & & & & Z-E & 0.226 & 1 \\
\hline \multirow[t]{2}{*}{ N Exposure } & 2.790 & $0.0054 * *$ & & & Z-N & 16.663 & $0.00022 * * *$ \\
\hline & & & & & Z-S & 0.012 & 1 \\
\hline \multirow[t]{2}{*}{ S Exposure } & 0.080 & 0.9361 & & \multirow[t]{3}{*}{ Exposure } & E-N & 19.259 & $0.00006^{* * *}$ \\
\hline & & & & & E-S & 0.316 & 1 \\
\hline C Canopy & 1.028 & 0.3044 & & & $\mathrm{~N}-\mathrm{S}$ & 14.510 & $0.00055^{* * *}$ \\
\hline \multirow[t]{2}{*}{ E Exposure/C Canopy } & -0.243 & 0.8084 & \multirow{6}{*}{$\begin{array}{c}\text { Mean } \\
\text { basal area } \pm \operatorname{EE}\left(\mathrm{m}^{2}\right)\end{array}$} & \multirow{2}{*}{ Canopy } & $\mathrm{O}$ & $0.0309 \pm 0.00324$ & \\
\hline & & & & & $\mathrm{C}$ & $\mathbf{0 . 0 3 9 0} \pm \mathbf{0 . 0 0 3 2 6}$ & \\
\hline \multirow[t]{2}{*}{ N Exposure/C Canopy } & 0.156 & 0.8757 & & \multirow[t]{4}{*}{ Exposure } & $Z$ & $0.0292 \pm 0.0043$ & \\
\hline & & & & & $\mathrm{E}$ & $0.0262 \pm 0.0046$ & \\
\hline \multirow[t]{2}{*}{ S Exposure/C Canopy } & 0.002 & 0.9987 & & & $\mathrm{~N}$ & $0.0554 \pm 0.0047$ & \\
\hline & & & & & $\mathrm{S}$ & $0.0299 \pm 0.0047$ & \\
\hline
\end{tabular}

*significance at $0.1 * *$ significance at $0.01 * * *$ significance at 0.001 . The highest mean basal area is highlighted.

Tree density did not differ significantly among terrain aspects; nor between canopy types, there was no significant interaction between factors either (Appendix 4).

\section{DISCUSSION}

The composition of tree species in the Natural Protected Area La Martinica is similar to that found by García-Franco et al. (2008), Muñiz-Castro et al. (2006), Ruiz-Montiel et al. (2014), Williams-Linera (2002) in other fragments of humid mountain forests in the region. The species richness (37 species) registered was higher than that indicated by García-de la Cruz et al. (2013) and Williams-Linera et al. (2005), who recorded 14 species and a ranging from three to 23 taxa in mature forest, and from nine to 31 in second-growth forest condition (acahual), respectively. However, there were less than those 58 species recorded by Ruiz-Montiel et al. (2014) and also than those registered in the forests studied by WilliamsLinera and López-Gómez et al. (2008) with a little more than 50 species. A plausible explanation is that, in our sampling, trees with ND $<10 \mathrm{~cm}$ were not included, as it was the case in those cited studies. Forest regrowth species were excluded, in addition to the eventual differences in sampling.

The second species with a high importance value was $C$. tropicalis, which coincides with the analysis of Ruiz-Jiménez et al. (2012). Those authors state that, for the HMFs of the Gulf of Mexico, it is common for C. tropicalis to be one of the dominant species. Several species that have high importance values, match results with García-de la Cruz et al. (2013) and Williams-Linera (2002). Both studies identified Clethra mexicana, Liquidambar styraciflua, Quercus germana and Quercus xalapensis as dominant species in the HMFs of the central region of Veracruz. However, in our study Lippia myriocephala had higher structural values, which indicates that it is a secondary forest, which has been formerly subject to disturbances (González-Zamora et al., 2016).

The structural patterns observed in the north aspect would be related to the resilient responses that have been observed in this terrain aspect after disturbances, since these lands appear to conserve more species, compared to the south aspect. Such a resilient process facilitates the regeneration of plant communities 


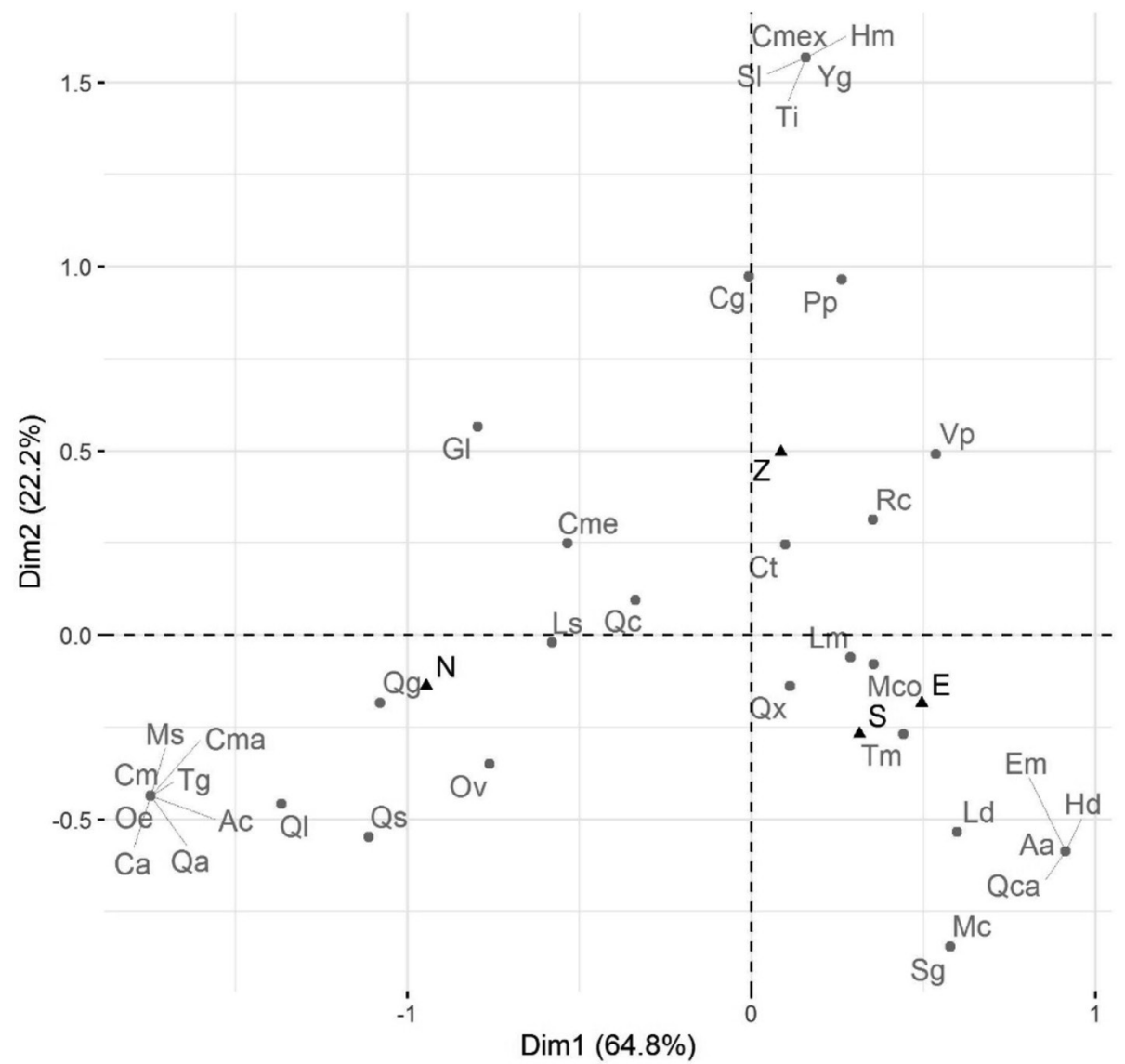

Fig. 5. Association of tree species and terrain aspect $(\mathrm{Z}=$ zenithal, $\mathrm{E}=$ east, $\mathrm{N}=$ north, $\mathrm{S}=$ south $) ;\left(\chi^{2}=352.4, \mathrm{P}<0.0001\right)$, based on the correspondence analysis. $\mathrm{Aa}=$ Alnus acuminata, $\mathrm{Ac}=$ Ardisia compressa, $\mathrm{Ct}=$ Carpinus tropicalis, $\mathrm{Cm}=$ Citharexylum mocinnoi, $\mathrm{Cme}=$ Clethra mexicana, $\mathrm{Cma}=$ Clethra macrophylla, $\mathrm{Ca}=$ Conostegia arborea, $\mathrm{Cg}=$ Cornutia grandifolia, $\mathrm{Cmex}=$ Clethra mexicana, $\mathrm{Em}=$ Erythrina macrophylla, $\mathrm{Gl}=$ Gymnanthes longipes, $\mathrm{Hm}=$ Hedyosmum mexicanum, $\mathrm{Hd}=$ Heliocarpus donnellsmithii, $\mathrm{Ld}=$ Leucaena diversifolia, $\mathrm{Lm}=$ Lippia myriocephala, $\mathrm{Ls}=$ Liquidambar styraciflua, $\mathrm{Ms}=$ Magnolia schiedeana, $\mathrm{Mc}=$ Morella cerifera, $\mathrm{Mco}=$ Myrsine coriacea, $\mathrm{Oe}=$ Ocotea effusa, Ov $=$ Ostrya virginiana, $\mathrm{Pp}=$ Pinus pseudostrobus, $\mathrm{Qc}=$ Quercus corrugata, $\mathrm{Qg}=$ Quercus germana, $\mathrm{Q} \mathrm{l}=$ Quercus leiophylla, $\mathrm{Qx}=$ Quercus xalapensis, $\mathrm{Qa}=$ Quercus acutifolia, $\mathrm{Qca}=$ Quercus candicans, $\mathrm{Qs}=$ Quercus salicifolia, $\mathrm{Rc}=$ Rhamnus capreifolia, $\mathrm{Sg}=$ Styrax glabrescens, $\mathrm{Sl}=$ Symplocos limoncillo, $\mathrm{Tg}=$ Telanthophora grandifolia, $\mathrm{Tm}=$ Trema micrantha, $\mathrm{Ti}=$ Turpinia insignis, $\mathrm{Vp}=$ Vachellia pennatula, $\mathrm{Yg}=$ Yucca guatemalensis.

(Åström et al., 2007). This coincides with Williams-Linera et al. (2002) who pointed out that in the case of the HMF located at west of Xalapa, Veracruz, the best conserved forests are on very steep slopes, facing further north; while the disturbed forests are in greater measure to the south facing slopes and also WilliamsLinera (2007) indicated that those rarest tree species in the HMFs of Veracruz are restricted to high altitudes and slopes facing north.
The highest species richness in this study was found in north-facing sites, which coincides with that recorded by Bale et al. (1998) who found higher species richness in the Polar aspect compared to the Equatorial one in Australian forests. Santiago-Pérez et al. (2009) in a study of a HMF (mountain cloud forest) in western Mexico, they report, in a general way, a lower richness of arboreal species in a site with western exposure in relation to others 
located to the north and northwest. However, it should be mentioned that there are results contrary to ours, as mentioned by Luna-Vega et al. (2007) who report 12 and 18 tree species in two mountain cloud forest sites oriented to the north and southwest, respectively. From the above, it can be concluded that there is variation in the richness and plant diversity in the HMF depending on the aspect. It is pertinent to indicate that other researchers have mentioned that fragments of undisturbed forest in Veracruz have an orientation of slopes further north (Williams-Linera et al., 2002); also, López-Pérez et al. (2011) indicate that the HMF, in a region of the State of Mexico, thrives mainly on north-facing slopes, which is probably an indication of a greater richness and diversity in such areas. A plausible explanation is that mentioned by Holland and Steyn (1975), Mata-González et al. (2002) and Renaud et al. (2011), referring that slope facing north in the northern hemisphere, tend to be more humid which benefits different plant species; unlike south-facing slopes which receive more solar radiation and tend to be drier and warmer.

Tree diversity also differed between canopy types, it was greater in the closed canopy. In accordance with the above, Santiago-Pérez et al. (2009) compared different sites of the HMF through a gradient in which the HMF is associated with the Pine-oak Forest (POF) and secondary scrub (SS), the authors found that the richness and diversity were similar in HMFPOF, but the replacement of species was higher in SS, in addition to the density, diameters, basal area and canopy coverage were higher in HMF-POF than SS. González-Zamora et al. (2016), analyzed the tree diversity and species richness between two HMF sites (conserved and disturbed) and a coffee plantation located in this type of vegetation; the authors found a higher species richness in the conserved forest when comparing it with the disturbed site and the coffee plantation. Furthermore, the highest species diversity corresponded to the conserved site and the lowest to the disturbed site, and the greatest floristic dissimilarity occurred between both types of forest.
Basal area and tree density are similar to the forests studied by Williams-Linera and López-Gómez et al. (2008). However, the range of ND of the trees recorded by those authors was greater than that of our records, because they considered individuals with ND $\geq 5 \mathrm{~cm}$. The average ND of tree individuals in La Martinica $(17.8 \mathrm{~cm})$ was smaller than that reported by García-De la Cruz et al. (2013) who recorded $23.5 \mathrm{~cm}$. This fact indicates that Humid Mountain Forest in our research is a young secondary forest. Also, wider trees than $1 \mathrm{~m} \mathrm{ND}$ were not found, which coincides with those observations by Williams-Linera (2007), who noted that those trees with larger diameters in Veracruz are scarce, and found in forests located at higher altitudes, farther away from large human settlements.

Tree density in north aspect was no greater than those in other terrain aspects as it was recorded by Måren et al. (2015). Nevertheless, individuals with a larger basal area were found, which coincides with what was observed by Luna-Vega et al. (2007) when they compared two HMF sites in central Mexico; the authors found a greater basal area, canopy coverage and a general difference in the maximum values of the stem of the trees of the site with north aspect in relation to the trees of the southwest site. These results probably indicate a higher biomass production in the north aspect, as it was verified in the studies of Gong et al. (2008) and Sternberg and Shoshany (2001) who found greater productivity and species diversity on slopes facing north compared to those facing south.

Ethical statement: the authors declare that they all agree with this publication and made significant contributions; that there is no conflict of interest of any kind; and that we followed all pertinent ethical and legal procedures and requirements. All financial sources are fully and clearly stated in the acknowledgements section. A signed document has been filed in the journal archives.

See Digital Appendix at: revistas.ucr.ac.cr 


\section{ACKNOWLEDGMENTS}

This study was supported by the Consejo Nacional de Ciencia y Tecnología (CONACyT) through the Postgraduate scholarship (461593) granted to the first author at Colegio de Postgraduados. We thank to the Secretaría de Medio Ambiente of Veracruz State (SEDEMA), for the authorization of the scientific research in La Martinica. We thank to Secretaría del Medio Ambiente y Recursos Naturales (SEMARNAT) for granting the scientific collection license. We thank to Erik David Murrieta Ruiz for his support in the field survey.

\section{RESUMEN}

\section{Estructura y diversidad arbórea de un bosque húmedo de montaña en el Área Natural Protegida La Martinica, Veracruz, México}

Introducción: El Bosque Húmedo de Montaña (BHM) posee el mayor número de especies vegetales por unidad de superficie, cuya vegetación se desarrolla en condiciones ambientales muy heterogéneas y presenta una alta variación florística. La conservación del BHM es importante debido a la biodiversidad que alberga y los servicios ambientales que proporciona.

Objetivo: Este trabajo evaluó el efecto de la orientación del terreno y la densidad del dosel del bosque sobre la estructura y diversidad arbórea en el Área Natural Protegida La Martinica, México.

Métodos: Se efectuó un muestreo estratificado en cuatro orientaciones del terreno y dos condiciones de densidad del dosel; se consideraron 25 unidades de muestreo de 20 x $25 \mathrm{~m}$, en las que se registró: el diámetro normal (DN), la altura total y los diámetros mayor y menor de la copa de los individuos con un $\mathrm{DN} \geq 10 \mathrm{~cm}$. La diversidad se estimó por medio de curvas de rarefacción y la estructura se analizó con el índice de valor de importancia (IVI) y el índice de valor forestal (IVF).

Resultados: Se registraron 37 especies pertenecientes a 30 géneros y 24 familias. Se observó una mayor diversidad en la orientación norte y en el dosel cerrado. Las especies arbóreas con valores estructurales más altos fueron diferentes entre orientaciones y tipos de dosel; Carpinus tropicalis presentó los valores más elevados en la orientación cenital, Lippia myriocephala en las orientaciones este y sur, y Liquidambar styraciflua en la norte. En ambos tipos de dosel Lippia myriocephala obtuvo los valores más altos del IVI e IVF en el dosel abierto; Carpinus tropicalis alcanzó un IVF más elevado en el dosel cerrado.

Conclusiones: La estructura arbórea fue diferente en las cuatro orientaciones estudiadas y en las dos condiciones del dosel. La mayor diferencia en composición de especies y diversidad se observó entre las orientaciones norte y este, de ellas, la norte presentó los valores más altos de riqueza, especies frecuentes y dominantes.

Palabras clave: apertura del dosel; número efectivo de especies; NMDS; orientación del terreno; vegetación arbórea.

\section{REFERENCES}

APG IV. (2016). An update of the Angiosperm Phylogeny Group classification for the order and families of flowering plants: APG IV. Botanical Journal of the Linnean Society, 181(1), 1-20. https://dx.doi. org/10.1111/boj.12385

Åström, M., Dynesius, M., Hylander, K., \& Nilsson, C. (2007). Slope aspect modifies community responses to clear-cutting in boreal forests. Ecology, 88(3), 749-758. https://doi.org/10.1890/06-0613

Bale, C. L., Williams, J. B., \& Charley, J. L. (1998). The impact of aspect on forest structure and floristics in some Eastern Australian sites. Forest Ecology and Management, 110(1-3), 363-377. https://doi. org/10.1016/S0378-1127(98)00300-4

Barcena, A. (1981). Clethraceae. In A. Gómez-Pompa \& V. Sosa (Eds.), Flora de Veracruz 15. INECOL.

Cayuela, L., Golicher, D. J., \& Rey-Benayas, J. M. (2006). The Extent, Distribution, and Fragmentation of Vanishing Montane Cloud Forest in the Highlands of Chiapas, Mexico. Biotropica, 38(4), 544-554.

Challenger, A., \& Soberón, J. (2008). Los ecosistemas terrestres. In J. Soberón, G. Halffter, \& J. LlorenteBousquets (Comps.), Capital natural de México, vol. I: Conocimiento actual de la biodiversidad (pp. 87-108). CONABIO.

Chao, A., Gotelli, N. J., Hsieh, T. C., Sander, E. L., Ma, K. H., Colwell, R. K., \& Ellison, A. M. (2014). Rarefaction and extrapolation with Hill numbers: a framework for sampling and estimation in species diversity studies. Ecological Monographs, 84(1), 45-67. https://doi.org/10.1890/13-0133.1

Chao, A., \& Jost, L. (2012). Coverage-based rarefaction and extrapolation: standardizing samples by completeness rather than size. Ecology, 93(12), 2533-2547. https://doi.org/10.1890/11-1952.1

CONAFOR \& COLPOS (Comisión Nacional Forestal \& Colegio de Postgraduados). (2014). Foresta Mexicana. CONAFOR, México.

Corella-Justavino, F., Valdez-Hernández, J. I., Cetina-Alcalá, V. M., González-Cossio, F. V., Trinidad-Santos, A., \& Aguirre-Rivera, J. R. (2001). Estructura forestal de un bosque de mangles en el noreste del estado 
de Tabasco, México. Ciencia Forestal en México, 26(90), 73-102.

Crawley, M. J. (2012). The R book. John Wiley \& Sons.

Cruz-Cárdenas, G., Villaseñor, J. L., López-Mata, L., \& Ortiz, E. (2012). Potential distribution of humid mountain forest in Mexico. Botanical Sciences, 90(3), 331-340. https://doi.org/10.17129/botsci.394

Cultid-Medina, C. A., \& Escobar, F. (2019). Pautas para la estimación y comparación estadística de la diversidad biológica (qD). In C. E. Moreno (Ed.), La biodiversidad en un mundo cambiante: Fundamentos teóricos y metodológicos para su estudio (pp. 175-202). Universidad Autónoma del Estado de Hidalgo/Libermex, México.

Curtis, J. T., \& McIntosh, R. P. (1951). An upland forest continuum in the prairie-forest border region of Wisconsin. Ecology, 32(3), 476-496. https://doi. org/10.2307/1931725

Endara-Agramont, A. R., Maass, S. F., Bernal, G. N., Valdez-Hernández, J. I., \& Fredericksen, T. S. (2012). Effect of human disturbance on the structure and regeneration of forests in the Nevado de Toluca National Park, Mexico. Journal of Forestry Research, 23(1), 39-44. https://doi.org/10.1007/s11676-012-0226-8

Fernández-Nava, R. (1986). Rhamnaceae. In A. GómezPompa, \& L. Cabrera-Rodríguez (Eds.), Flora de Veracruz 50. INECOL

Ferrari, D. M., Pozzolo, O. R., \& Ferrari, H. J. (2006). CobCal v 1.0. Instituto Nacional de Tecnología Agropecuaria, Uruguay. http://www.cosechaypostcosecha. org/data/articulos/varios/DesarrolloSoftEstimacionCoberturaVegetal.asp

García, E. (2004). Modificaciones al sistema de clasificación climática de Köppen. Instituto de GeografíaUNAM, México.

García-de la Cruz, Y., Olivares-López, L. A., \& RamosPrado, J. M. (2013). Estructura y composición arbórea de un fragmento de bosque mesófilo de montaña en el estado de Veracruz. Revista Chapingo Serie Ciencias Forestales y del Ambiente, 19(1), 91-101. http://dx.doi.org/10.5154/r.rchscfa.2012.03.025

García-Franco, J. G., Castillo-Campos, G., Mehltreter, K., Martínez, M. L., \& Vázquez, G. (2008). Estructura y composición de un bosque mesófilo del centro de Veracruz, México. Boletín de la Sociedad Botánica de México, 83, 37-52. https://doi.org/10.17129/ botsci. 1787

Gong, X., Brueck, H., Giese, K. M., Zhang, L., Sattelmacher, B., \& Lin, S. (2008). Slope aspect has effects on productivity and species composition of hilly grassland in the Xilin River Basin, Inner Mongolia, China. Journal of Arid Environments, 72(4), 483493. https://doi.org/10.1016/j.jaridenv.2007.07.001
González-Espinosa, M., Meave, J. A., Lorea-Hernández, F. G., Ibarra-Manríquez, G., \& Newton, A. C. (Eds.). (2011). The Red List of Mexican Cloud Forest Trees. Fauna \& Flora International.

González-Espinosa, M., Meave, J. A., Ramírez-Marcial, N., Toledo-Aceves, T., Lorea-Hernández, F. G., \& Ibarra-Manríquez, G. (2012). Los bosques de niebla de México: conservación y restauración de su componente arbóreo. Ecosistemas, 21(1-2), 36-54.

González-Zamora, A., Esperón-Rodríguez, M., \& Barradas, V. L. (2016). Mountain cloud forest and grown-shade coffee plantations: A comparison of tree biodiversity in central Veracruz, Mexico. Forest Systems, 25(1), 10. https://doi.org/10.5424/fs/2016251-07538

Gual-Díaz, M., \& Rendón-Correa, A. (comps.). (2014). Bosques mesófilos de montaña en México: diversidad, ecología y manejo. CONABIO.

Gual-Díaz, M., \& Rendón-Correa, A. (2017). Los bosques mesófilos de montaña de México. Agroproductividad, 10(1), 3-9.

Guerrero-Hernández, R., Muñiz-Castro, M. Á., VázquezGarcía, J. A., \& Ruiz-Corral, J. A. (2019). Estructura del bosque mesófilo de montaña y su reemplazo por bosque de Abies en dos gradientes altitudinales del occidente de México. Botanical Sciences, 97(3), 301-322. https://doi.org/10.17129/botsci.2206

Herrera-Beltrán, F. (16 de junio de 2010). Decreto por el que se declara Área Natural Protegida en la categoría de Reserva Ecológica La Martinica, Localizada en el Municipio de Banderilla, Veracruz. Xalapa, México. Editora del Gobierno del Estado de Veracruz.

Holland, P. G., \& Steyn, D. G. (1975). Vegetational responses to latitudinal variations in slope angle and aspect. Journal of Biogeography, 2(3), 179-183. https://doi. org/10.2307/3037989

Hsieh, T. C., Ma, K. H., \& Chao, A. (2020). iNEXT: iNterpolation and EXTrapolation for species diversity. (Version 2.0.20, R package). http://chao.stat.nthu. edu.tw/wordpress/software-download/

López-Gómez, A. M., Williams-Linera, G., \& Manson, R. H. (2008). Tree species diversity and vegetation structure in shade coffee farms in Veracruz, Mexico. Agriculture, Ecosystems \& Environment, 124(3-4), 160-172.

López-Pérez, Y., Tejero-Díez, J. D., Torres-Díaz, A. N., \& Luna-Vega, I. (2011). Flora del bosque mesófilo de montaña y vegetación adyacente en Avándaro, Valle de Bravo, Estado de México, México. Boletín de la Sociedad Botánica de México, 88, 35-53.

Ludlow-Wiechers, B. (1978). Chloranthaceae. In A. Gómez-Pompa, \& V. Sosa (Eds.), Flora de Veracruz 3. INECOL. 
Luna-Vega, I., Alcántara-Ayala, O., Contreras-Medina, R., \& Ruiz-Jiménez, C. A. (2007). Composición y estructura del bosque mesófilo de montaña de Ocuilan, Estado de México-Morelos. In I. Luna-Vega, J. J. Morrone, \& D. Espinosa-Organista (Eds.), Biodiversidad de la Faja Volcánica Transmexicana (pp. 173-178). UNAM.

Manson, R. H. (2017). El papel del bosque mesófilo de montaña en los programas "pagos por servicios ambientales hidrológicos" en México. Agroproductividad, 10(1), 44-49.

Måren, I. E., Karki, S., Prajapati, C., Yadav, R. K., \& Shrestha, B. B. (2015). Facing north or south: Does slope aspect impact forest stand characteristics and soil properties in a semiarid trans-Himalayan valley? Journal of Arid Environments, 121, 112-123. https:// doi.org/10.1016/j.jaridenv.2015.06.004

Mata-González, R., Pieper, R. D., \& Cárdenas, M. M. (2002). Vegetation patterns as affected by aspect and elevation in small desert mountains. The Southwestern Naturalist, 47(3), 440-448. https://doi. org/10.2307/3672501

Muñiz-Castro, M. A., Williams-Linera, G., \& Benayas, J. M. R. (2006). Distance effect from cloud forest fragments on plant community structure in abandoned pastures in Veracruz, Mexico. Journal of Tropical Ecology, 22, 431-440. https://doi.org/10.1017/ S0266467406003221

Nash, D. L., \& Nee, M. (1984). Verbenaceae. In A. GómezPompa, \& N. P. Moreno (Eds.), Flora de Veracruz 41. INECOL.

Nee, M. (1981). Betulaceae. In A. Gómez-Pompa, \& V. Sosa (Eds.), Flora de Veracruz 20. INECOL.

Nenadic, O., \& Greenacre, M. (2007). Correspondence Analysis in R, with two- and three-dimensional graphics: The ca package. Journal of Statistical Software, 20(3), 1-13. http://hdl.handle.net/10.18637/ jss.v020.i03

Oksanen, J., Blanchet, F. G., Friendly, M., Kindt, R., Legendre, P., McGlinn, D., Minchin, P. R., O'Hara, R. B., Simpson, G. L., Solymos, P., Stevens, M. H. H., Szoecs, E., \& Wagner, H. (2019). Vegan: Community Ecology Package (version 2.5-6, R package). https://CRAN.R-project.org/package=vegan

Ortega-Baranda, V., Valdez-Hernández, J. I., García-Moya, E., \& Rodríguez-Trejo, D. A. (2017). Structure and diversity of tree vegetation in three reliefs on the Oaxaca coast. Revista Chapingo Serie Ciencias Forestales y del Ambiente, 23(2), 173-184. https:// doi.org/http:/dx.doi.org/10.5154/r.rchscfa

Pacheco, L. (1983). Styracaceae. In A. Gómez-Pompa \& V. Sosa (Eds.), Flora de Veracruz 20. INECOL.
R Core Team. (2019). $R$ : A language and environment for statistical computing (Version 3.6.2). R Foundation for Statistical Computing. Vienna, Austria. https:// www.R-project.org/

Renaud, V., Innes, J. L., Dobbertin, M., \& Rebetez, M. (2011). Comparison between open-site and belowcanopy climatic conditions in Switzerland for different types of forests over 10 years (1998-2007). Theoretical and Applied Climatology, 105(1-2), 119-127. https://doi.org/10.1007/s00704-010-0361-0

Rosario-Martinez, H. (2015). phia: Post-Hoc Interaction Analysis. (version $0.2-1, \mathrm{R}$ package). https:// CRAN.R-project.org/package $=$ phia

Ruiz-Jiménez, C. A., Téllez-Valdés, O., \& Luna-Vega, I. (2012). Clasificación de los bosques mesófilos de montaña de México: afinidades de la flora. Revista Mexicana de Biodiversidad, 83(4), 1110-1144. http:// dx.doi.org/10.7550/rmb.29383

Ruiz-Montiel, C., Vázquez-Torres, V., Martínez-Hernández, M., Murrieta-Pérez, L., \& Perea-Hernández, M. S. (2014). Árboles y arbustos registrados en el parque ecológico Molino de San Roque, Municipio de Xalapa, Veracruz. Madera y Bosques, 20(2), 143-152. https://doi.org/10.21829/myb.2014.202170

Rzedowski, J. (2006). Vegetación de México (1ra. Edición digital). CONABIO.

Sánchez-Gutiérrez, F., Valenzuela-Gómez, A., Valdez-Hernández, J. I., \& González-González, C. A. (2017). Estructura y diversidad de especies arbóreas en el sitio arqueológico "El Mirador", Selva Lacandona, Chiapas. Polibotánica, 44, 79-94. http://dx.doi org/10.18387/polibotanica.44.6

Santana, G., Mendoza, M., Salinas, V., Pérez-Salicrup, D., Martínez., Y., \& Aburto, I. (2014). Análisis preliminar de la diversidad y estructura arbórea-arbustiva del bosque mesófilo en el Sistema Volcánico Transversal de Michoacán, México. Revista Mexicana de Biodiversidad, 85, 1104-1116. https://doi.org/ 10.7550/ rmb.41519

Santiago-Pérez, A. L., Jardel-Peláez, E. J., Cuevas-Guzmán, R., \& Huerta-Martínez, F. M. (2009). Vegetación de bordes en un bosque mesófilo de montaña del occidente de México. Boletín de la Sociedad Botánica de México, 85, 31-49.

SEDESMA. (2006). Programa de manejo del área natural "La Martinica". Secretaría de Desarrollo Social y Medio Ambiente de Veracruz (SEDESMA).

Sternberg, M., \& Shoshany, M. (2001). Influence of slope aspect on Mediterranean woody formations: comparison of a semiarid and an arid site in Israel. Ecological Research, 16(2), 335-345. https://doi. org/10.1046/j.1440-1703.2001.00393.x 
Stevens, P. F. (2017, Julio). Angiosperm Phylogeny Website. http://www.mobot.org/MOBOT/research/APweb/

Toledo-Aceves, T., Meave, J. A., González-Espinosa, M., \& Ramírez-Marcial, N. (2011). Tropical montane cloud forests: Current threats and opportunities for their conservation and sustainable management in Mexico. Journal of Environmental Management, 92, 974-981.

Torres, E., Schwarzkopf, T., Fariñas, M. R., \& Aranguren, A. (2012). ¿Es la orientación de la pendiente un factor modificador de la estructura florística en la alta montaña tropical andina? Ecotrópicos, 25(2), 61-74.

TROPICOS. (2018). Tropicos.org. Missouri Botanical Garden. http://www.tropicos.org

Villaseñor, J. L. (2010). El bosque húmedo de montaña en México y sus plantas vasculares. Catálogo florísticotaxonómico. CONABIO-UNAM.

Williams-Linera, G. (2002). Tree species richness complementarity, disturbance and fragmentation in a Mexican tropical montane cloud forest. Biodiversity \& Conservation, 11(10), 1825-1843. https://doi. org/10.1023/A:1020346519085

Williams-Linera, G. (2007). El bosque de niebla del centro de Veracruz: ecología, historia y destino en tiempos de fragmentación y cambio climático. CONABIO-INECOL.

Williams-Linera, G., Guillén Servent, A., Gómez García, O., \& Lorea Hernández, F. (2007). Conservación en el centro de Veracruz, México. El bosque de niebla: ¿reserva archipiélago o corredor biológico? In G. Halffter, S. Guevara, \& A. Melic (Eds.), Hacia una cultura de conservación de la diversidad biológica (pp. 303-310). Sociedad Entomológica Aragonesa, Comisión Nacional para el Conocimiento y Uso de la Biodiversidad, Comisión Nacional de Áreas Naturales Protegidas, Consejo Nacional de Ciencia y Tecnología.

Williams-Linera, G., \& López-Gómez, A. (2008). Estructura y diversidad de la vegetación leñosa. In R. H. Manson, V. Hernández-Ortíz, S. Gallina, \& K. Mehltreter (Eds.), Agroecosistemas cafetaleros de Veracruz: biodiversidad, manejo y conservación. (pp. 55-68). INECOL-SEMARNAT.

Williams-Linera, G., López-Gómez, A. M., \& MuñizCastro, M. A. (2005). Complementariedad y patrones de anidamiento de especies de árboles en el paisaje de bosque de niebla del centro de Veracruz (México). In G. Halffter, J. Soberón, P. Koleff, \& A. Melic (Eds.), Sobre Diversidad Biológica: El Significado de las diversidades alfa, beta y gamma (pp. 153-164). CONABIO-SEA-CONACyT.

Williams-Linera, G., Manson, R. H., \& Vera, E. I. (2002). La fragmentación del bosque mesófilo de montaña y patrones de uso del suelo en la región oeste de Xalapa, Veracruz, México. Madera y Bosques, 8(1), 73-89. https://doi.org/10.21829/myb.2002.811307

Williams-Linera, G., Toledo-Garibaldi, M., \& Gallardo Hernández, C. (2013). How heterogeneous are the cloud forest communities in the mountains of central Veracruz, Mexico? Plant Ecology, 214, 685-701. https://doi.org 10.1007/s11258-013-0199-5 